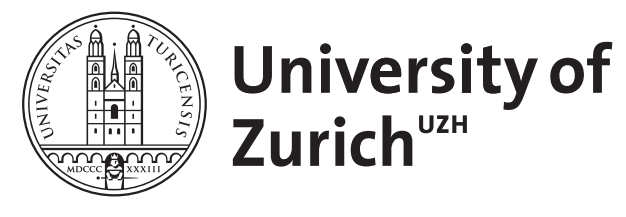

\title{
Human endothelial dysfunction: EDRFs
}

\author{
Flammer, Andreas J ; Lüscher, Thomas F
}

\begin{abstract}
Since the detection of nitric oxide two and a half decades ago, there has been an incredible boost in endothelial function research, which is fascinating the research community. Physiologically, endothelial cells synthesize a number of vasoactive substances. In particular, several endothelium-derived relaxing factors (EDRFs) have been characterized, whereby nitric oxide is the most important. In humans, endothelial dysfunction is one of the first clinically detectable alterations in the development of atherosclerosis and is characterized by an imbalance in the release of vasoactive substances. Thus, it is the aim of this article to give an overview about endothelial function in humans, to summarize the different possibilities to assess endothelial function in this species, and to give an overview of the role of EDRFs in different cardiovascular diseases
\end{abstract}

DOI: https://doi.org/10.1007/s00424-010-0822-4

Posted at the Zurich Open Repository and Archive, University of Zurich ZORA URL: https://doi.org/10.5167/uzh-156725

Journal Article

Published Version

Originally published at:

Flammer, Andreas J; Lüscher, Thomas F (2010). Human endothelial dysfunction: EDRFs. Pflügers Archiv : European Journal of Physiology, 459(6):1005-1013.

DOI: https://doi.org/10.1007/s00424-010-0822-4 


\title{
Human endothelial dysfunction: EDRFs
}

\author{
Andreas J. Flammer • Thomas F. Lüscher
}

Received: 25 February 2010 /Revised: 3 March 2010 / Accepted: 4 March 2010 /Published online: 12 April 2010

(C) Springer-Verlag 2010

\begin{abstract}
Since the detection of nitric oxide two and a half decades ago, there has been an incredible boost in endothelial function research, which is fascinating the research community. Physiologically, endothelial cells synthesize a number of vasoactive substances. In particular, several endothelium-derived relaxing factors (EDRFs) have been characterized, whereby nitric oxide is the most important. In humans, endothelial dysfunction is one of the first clinically detectable alterations in the development of atherosclerosis and is characterized by an imbalance in the release of vasoactive substances. Thus, it is the aim of this article to give an overview about endothelial function in humans, to summarize the different possibilities to assess endothelial function in this species, and to give an overview of the role of EDRFs in different cardiovascular diseases.
\end{abstract}

Keywords Endothelium $\cdot$ Endothelium-derived relaxing factor $(E D R F) \cdot$ Nitric oxide $\cdot$ Prostacyclin . Endothelium-derived hyperpolarizing factor

A. J. Flammer · T. F. Lüscher

Cardiovascular Center, Cardiology University Hospital Zurich,

Zurich, Switzerland

T. F. Lüscher

Institute of Physiology, Cardiovascular Research,

University Zürich-Irchel,

Zürich, Switzerland

T. F. Lüscher $(\bowtie)$

Cardiology and Cardiovascular Physiology,

University Hospital Zurich,

Ramistrasse 100,

8091 Zurich, Switzerland

e-mail: cardiotfl@gmx.ch

\section{Introduction}

In the past, the endothelium was believed to be just a simple semipermeable membrane lining the inner part of arteries, veins, and lymphatic vessels. In the last three decades, however, thanks to extensive research in this field, it became apparent that this cellular monolayer is fundamental for the homeostasis of vascular tone (Fig. 1).

In humans, endothelial dysfunction is one of the first clinically detectable alterations in the development of atherosclerosis. In recent years, a number of studies assessing endothelial function have been performed in healthy subjects, as well as in patients. Through this research, the role of endothelial cells in health and cardiovascular disease could be largely defined. Clinical studies have been performed in several vascular beds, including the forearm vasculature, the microcirculation of different organs, as well as the coronary circulation. It is the aim of this article to summarize the different possibilities to assess endothelial function in humans and to give an overview of the role and alterations of endothelium-derived relaxing factors (EDRFs) in different cardiovascular diseases.

\section{Methods for assessing human endothelial dysfunction}

Several methods have been developed in recent years; however, an optimal methodology does not exist so far, and hence, there is no clear gold standard. The different techniques used all have their advantages and disadvantages and allow for the investigation of different vascular beds.

Mainly large conduit arteries are able to dilate in response to reactive hyperemia (i.e., flow-mediated vasodilatation) or receptor-operated agonists such as acetylcholine 


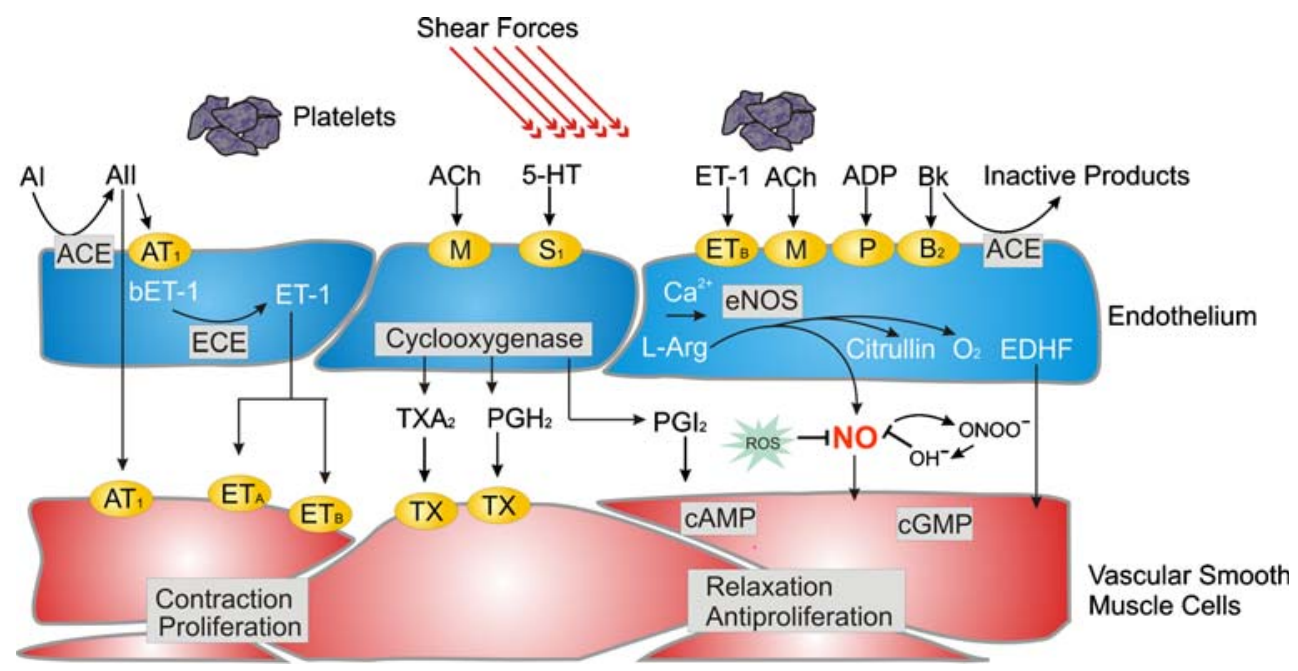

Fig. 1 Endothelium-derived vasoactive substances. Shear stress and activation of a variety of receptors leads to a release of nitric oxide $(N O)$ by inducing endothelial nitric oxide synthase. It exerts relaxation of vascular smooth muscle cells and exerts antiproliferative effects as well as inhibits thrombocyte aggregation and leucocyte adhesion. Other endothelium-derived relaxing factors including endotheliumderived hyperpolarizing factor $(E D H F)$ and prostacyclin $\left(P G I_{2}\right)$ are also shown. $A C E$ angiotensin-converting enzyme, Ach acetylcholine,

in the presence of an intact layer of endothelial cells. These responses are mediated by the release of nitric oxide (NO) or other vasodilator substances such as prostacyclin $\left(\mathrm{PGI}_{2}\right)$, able to activate smooth muscle cells (Fig. 1 and text below). Of note, not all blood vessels are able to dilate to the same extent in response to these stimuli, as the expression of specific endothelial receptors for these agonists as well as the intrinsic stiffness of a given blood vessel plays an important role. Nevertheless, independent by the technique used to assess function, a significant association between endothelial function and cardiovascular risk factors and disease has been noted. Indeed, in humans, endothelial dysfunction has been documented in the presence of most major cardiovascular risk factors including in arterial hypertension [59, 73], in normotensive individuals with a family history of hypertension [96], in active smokers [17, $116]$ and passive smokers [18], in dyslipidemia [15, 89], in aging subjects [59], in diabetes mellitus [13, 23, 62, 88, 91], in obesity [91], in hyperhomocysteinemia [105], and in patients with inflammatory or infectious diseases [36, 37, 48]. Moreover, a prognostic role of endothelial dysfunction of epicardial coronary arteries, as well as those of the peripheral circulation, has been documented $[8,40,43,45$, $67,81,84,85,94,104]$.

Flow-mediated vasodilatation:

The most important and widely used techniques to assess endothelial function in humans take advantage of the fact that endothelial cells release NO and other endothelium-
$A I$ angiotensin I, $A I I$ angiotensin II, $A T 1$ angiotensin 1 receptor, $B k$ bradykinin, $C O X$ cyclooxygenase, $E C E$ ET-converting enzyme, $E D H F$ endothelium-derived hyperpolarizing factor, $E T_{A}$ and $E T_{B}$ endothelin A and B receptors, ET-1 endothelin-1, L-Arg L-arginine, $\mathrm{PGH}_{2}$ prostaglandin $\mathrm{H}_{2}, \mathrm{ROS}$ reactive oxygen species, $\mathrm{S}_{1}$ serotoninergic receptor, $T H$ thromboxane receptor, $T h r$ thrombin, $T X A_{2}$ thromboxane, 5-HT serotonin

derived relaxing factors in response to blood flow induced shear stress. To measure this response in vivo, Celermajer et al. developed an elegant noninvasive technique to determine flow-mediated vasodilatation (FMD) of the brachial or radial artery in response to reactive hyperemia after short periods of total blockage of blood flow by a blood pressure cuff [16]. Thereby, the change in diameter of the studied blood vessel is assessed by ultrasound at baseline and during reactive hyperemia (Fig. 2). This response is mainly NO-mediated as demonstrated by Joannides et al. [50, 51] (Fig. 3). Moreover, at least in patient populations, peripheral endothelial function as assessed by FMD correlates with coronary artery endothelial function [3]. The method, however, does require extensive training and experience and suffers standardization. Several attempts have been made to standardize the technique and the different protocols $[20,26]$.

Venous occlusion plethysmography

Forearm venous plethysmography is a more invasive technique, as it typically requires cannulation of the brachial artery and intraarterial administration of substances, hormones, or drugs. The technique essentially measures changes in volume of the forearm during brief periods of venous occlusion and thereby measures blood flow rather than changes in large artery diameter (see above). Substances including acetylcholine, bradykinin, and serotonin or nitroglycerin are usually infused to measure endothelium-dependent and endothelium-independent va- 
Fig. 2 Flow-mediated vasodilatation. Schematic ultrasound images of the brachial artery at baseline, after reactive hyperemia induced flow-mediated vasodilatation and after nitroglycerin $(G T N)$ application, are shown. Blood pressure cuffs can be placed on the upper or the lower side of the transducer in the antecubital fossa; however, the latter is the preferred method. On the left hand side, the time course of an FMD measurement is shown [20]. See text for further explanation

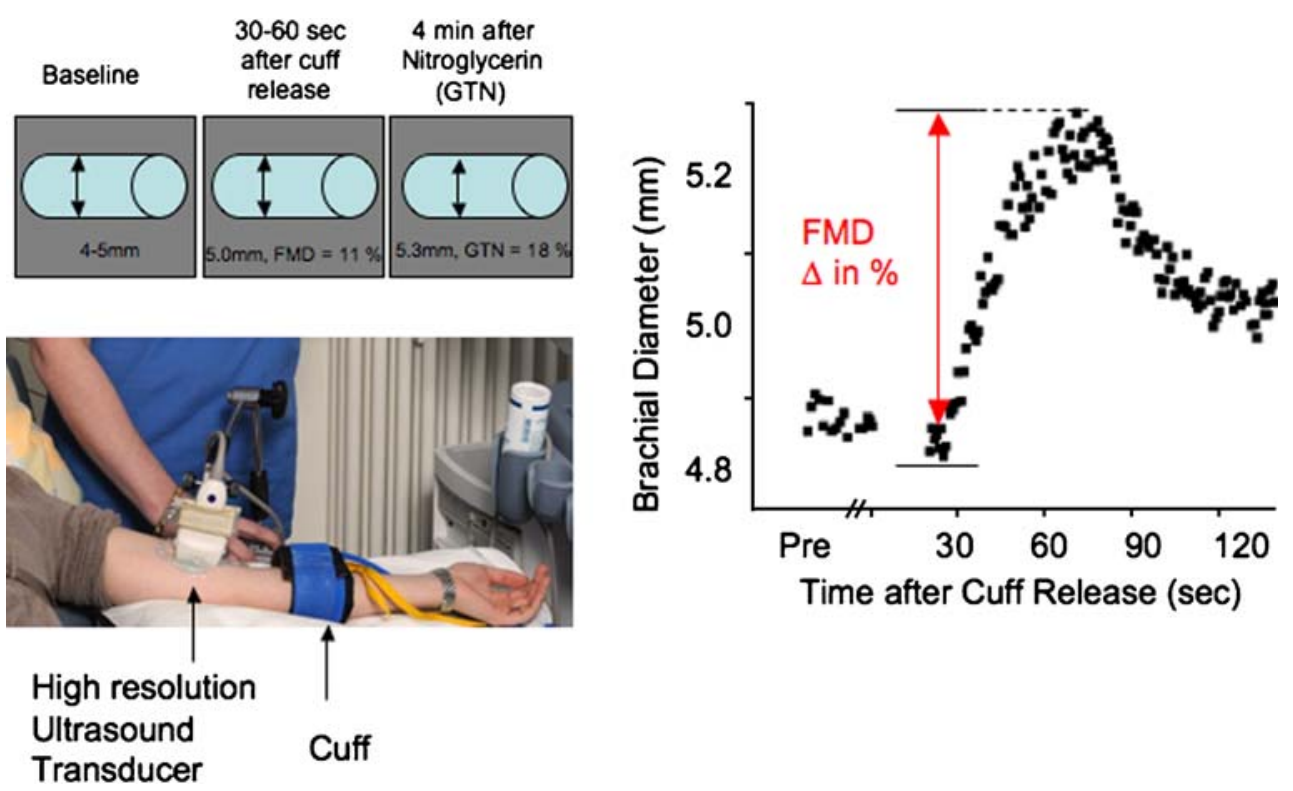

sodilatation, respectively (Fig. 4) [59, 73]. The advantage of this technique is the possibility to administer different agonists and antagonists and even novel substances at a systemically ineffective dose into the brachial artery, with the contralateral arm serving as a control. Changes in forearm blood flow as assessed by venous occlusion plethysmography are determined in both forearms, and results are expressed as the ratio of both arms. Although the microcirculation in the forearm is not a target organ of atherosclerosis, it seems that the response to acetylcholine has nevertheless an independent predictive value for future cardiovascular events [26].

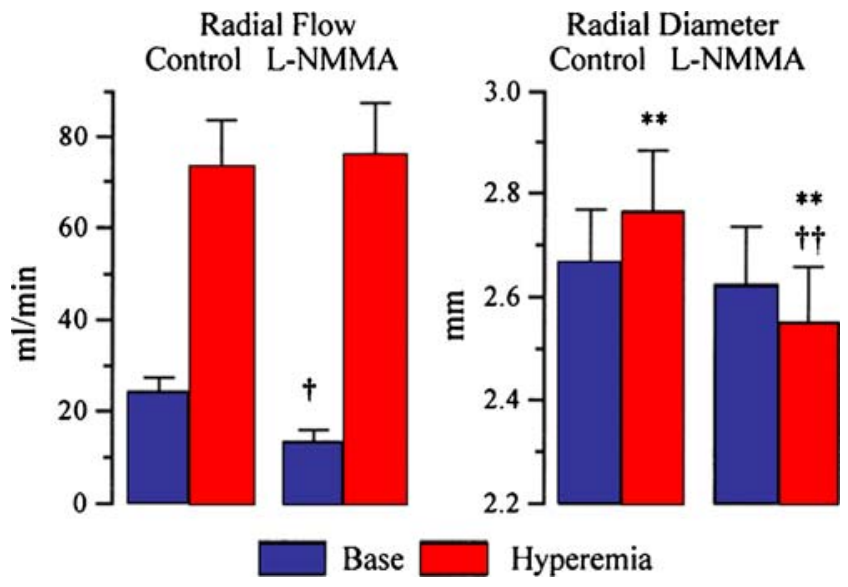

Fig. $3 \mathrm{NO}$ in flow-mediated vasodilatation. Radial artery flow (milliliters per minute) and radial artery diameter (millimeters) measured at baseline and during reactive hyperemia before and after infusion of $N G$-monomethyl-L-arginine $(L-N M M A)$. ${ }^{* *} P<.01$ vs base; $P<0.05$ and $P<0.01$ vs corresponding control value. Modified from Joannides et al. [50]
Coronary endothelial function measurements

Assessment of coronary endothelial function is always handicapped by its invasive nature. Indeed, it requires catheterization of usually the left coronary artery with an angiography catheter and the intracoronary infusion of acetylcholine, papaverine, or other substances such as Lmonomethyl arginine and the assessment of changes in coronary artery diameter by quantitative angiography. However, if performed appropriately by experienced operators, it provides very valuable information about the coronary vascular bed. Indeed, the healthy coronary circulation with a functionally intact endothelium will respond to intracoronary acetylcholine infusion with epicardial und microvascular relaxation resulting in vasodilatation and an increase of coronary blood flow. However, if the endothelium is dysfunctional, acetylcholine induces paradoxical vasoconstriction and a decrease in coronary blood flow [60]. The response to intracoronary acetylcholine has important prognostic impact and predicts future cardiovascular events [84].

Finger plethysmography

Recently, a finger plethysmographic device allowing the detection of pulsatile arterial volume changes has been introduced [56, 58]. Similar to the assessment of endothelial function via the FMD technique by ultrasound of the brachial artery, a pressure cuff is placed on one upper arm, while the other arm serves as a control. After measuring baseline blood volume changes, the blood pressure cuff is inflated above systolic pressure and is then deflated to induce reactive hyperemia on one arm. Similar volume 

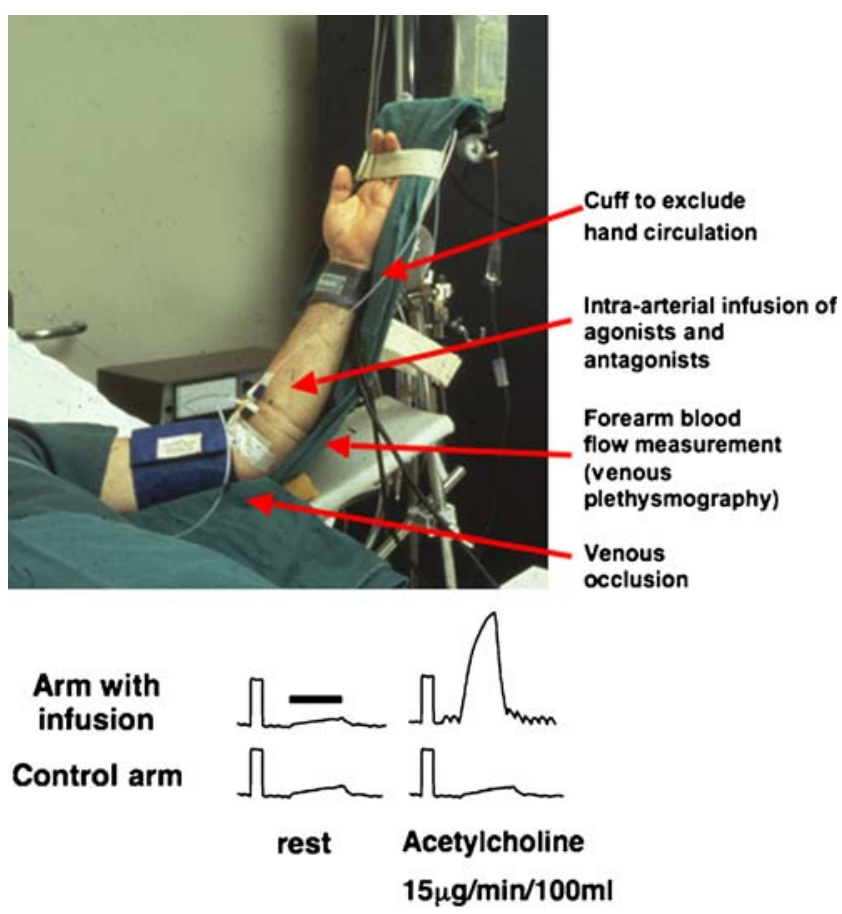

Fig. 4 Venous plethysmography. Demonstration of the strain-gauge venous plethysmography method to asses human peripheral endothelial microcirculatory function. The brachial artery is cannulated and substances including acetylcholine or nitroglycerin as well as drugs can be infused

changes after nitroglycerin can be measured. This technique tends to measure microvascular function.

Pulse wave analysis

With this noninvasive technique, the pulse-wave and velocity profile of the propagation of the arterial wave form and its reflected wave is assessed. The central aortic waveform is calculated as the augmentation index [115]. Although not the only contributor, endothelial function plays an important role in arterial stiffness and thus affects the results of this methodology as well. It therefore has been used to determine effects of endothelial mediators on arterial stiffness.

\section{Endothelium-derived relaxing factors in human endothelial function}

A considerable knowledge on the role of the endothelium in vascular homeostasis has accumulated as reflected by the contributions to this special issue on the endothelial saga. Physiologically, endothelial cells synthesize a number of antiatherogenic substances. In particular, several EDRFs have been characterized (Fig. 1). Most of them are released after an increase in intracellular calcium within endothelial cells in response to shear forces and/or receptor-operated mediators. Currently, the most extensively studied molecules are $\mathrm{NO}, \mathrm{PGI}_{2}$, and endothelium-derived hyperpolarizing factors (EDHF; Fig. 1).

The contribution of these mediators to endotheliumdependent dilatation is inversely related to the vessel size. Indeed, $\mathrm{NO}$ - and $\mathrm{PGI}_{2}$-mediated responses seem to be more important in conduit vessels, whereas EDHF seems to be more prominent in resistance arteries, particularly also in the coronary circulation [87].

\section{Nitric Oxide}

The term endothelium-derived relaxing factor was originally proposed by Robert Furchgott for a then unknown factor leading to relaxation of the smooth muscle of large arteries in response to acetylcholine. NO was later found to be the mediator of this response. NO is synthesized by the endothelial isoform of NO synthase (NOS) from its precursor L-arginine [71], which is inhibited by false substrates of the precursor of NOS, e.g., L-NG-monomethyl arginine (L-NMMA) [72]. NOS is a highly regulated protein and the endothelial isoform (eNOS) is predominantly found in endothelial cells. Its full function is dependent on activation of calmodulin and the presence of L-arginine and cofactors such as tetrahydrobiopterin $\left(\mathrm{BH}_{4}\right)$ $[1,92] . \mathrm{BH}_{4}$ supplementation increases $\mathrm{NO}$ synthesis in patients with hypercholesterolemia [24] and coronary artery disease [61].

NO is released from endothelial cells in response to activation of different receptors and especially to shear stress induced by blood flow (Fig. 1) [2, 39, 82]. The free radical has a very short half-life, easily crosses biological membranes and thus quickly diffuses from the endothelium to the vascular smooth muscle cell to activate soluble guanylyl cyclase which in turn induces an increase in cyclic guanosine monophosphate (cGMP) concentrations, thus leading to a relaxation of the smooth muscle cells with consequent vasodilatation (Fig. 1) [39, 70, 71, 90].

NO is a free radical which is scavenged for instance by reactive oxygen species (ROS) which play an important role in the pathogenesis of cardiovascular diseases. Rapid removal of ROS is important to protect cellular structures and NO from its inactivation. In many cardiovascular diseases, however, an increased oxidative stress is an important hallmark. For example, superoxide anion $\left(\mathrm{O}_{2}{ }^{-}\right)$, an oxygen radical, can scavenge $\mathrm{NO}$ to form peroxynitrite $\left(\mathrm{ONOO}^{-}\right)$, which effectively reduces the bioavailability of endothelium-derived NO and causes posttranscriptional modification of proteins such as superoxide dismutase and prostacyclin synthase and DNA damage [83, 109]. In addition, $\mathrm{O}_{2}{ }^{-}$directly may act as a vasoconstrictor $[4,22$, $52,53]$. A major source of $\mathrm{O}_{2}{ }^{-}$is the nicotinamide adenine 
dinucleotide (NADH) dehydrogenase, a mitochondrial enzyme of the respiratory chain [110]. Its expression in human coronary arterial smooth muscle cells is upregulated by pulsatile stretch, thus generating increased oxidative stress [47]. $\mathrm{O}_{2}^{-}$is finally degraded by superoxide dismutase (SOD), forming $\mathrm{H}_{2} \mathrm{O}_{2}$ which is further metabolized by catalase [38]. Unfortunately, the reaction between $\mathrm{O}_{2}{ }^{-}$and $\mathrm{NO}$ is three times faster than the detoxification of $\mathrm{O}_{2}{ }^{-}$by SOD [106]. Depending on the relative concentrations of $\mathrm{NO}$ and SOD, there may be a propensity for $\mathrm{O}_{2}{ }^{-}$to react preferentially with $\mathrm{NO}$, resulting in decreased bioavailability of NO with its detrimental consequences (see above). Oxidative stress therefore not only eliminates protective NO but also leads to lipid peroxidation and endothelial cell death.

Importantly, despite its vasodilatation properties, NO has also antithrombogenic, antiproliferative, leukocyte adhesioninhibiting effects, and influences myocardial contractility [2, $50,51,111]$. Hence, NO has a very powerful antiathrogenic profile and endothelial dysfunction with decreased NO levels therefore favors vascular dysfunction and atherosclerotic disease.

The important role of NO in humans is illustrated best with its effect on arterial blood pressure. Of note, NO release is an important contributor to basal vascular tone also in humans. Thus, inhibition of NOS for instance with L-NMMA leads to an increase in arterial blood pressure [2, $71,72,82,111]$.

\section{NO in cardiovascular disease}

With the above-mentioned techniques, endothelial function in vivo nowadays can be easily assessed in normal subjects as well as patients with cardiovascular risk factors or disease. Of interest, endothelium-dependent vasodilatation in response to acetylcholine is blunted in patients with hypertension, both in the forearm as well as in the coronary circulation [25, 46, 59, 73-77, 97-99] [31, 107]. Further, a reduced basal NO activity has been noted as the response to the NO inhibitor L-NMMA is significantly less in hypertensive patients compared with normotensive controls [12, 96]. Interestingly, normotensive offspring of hypertensive parents exhibit impaired endothelial function as assessed by the response to acetylcholine, and similar to patients with manifest hypertension, basal NO synthesis is already diminished [63]. Therefore, endothelial dysfunction in hypertension is at least in part caused by genetic factors and is not simply a consequence of the high arterial blood pressure [64]. Several genetic variations in the eNOS gene have been described [81]. Importantly, the diminished NO bioactivity is most likely due to an increase in ROS, which are able to scavenge NO [100].

In aging, the bioavailability of protective NO declines with a simultaneous increase in constricting factors. The reason for the decline in NO in the elderly is not fully understood. Some studies suggest a decrease in the NOS activity in aging [5, 108], whereas others do not [112]. Likely, oxidative stress is responsible because of a prolonged exposure to ROS, with an increasing number in dysfunctional mitochondria in endothelial cells. Elderly humans who perform regular physical training are able improve eNOS expression [102].

In active as well as passive smoking, a dose-related impairment in endothelial function due to a decreased eNOS activity has been demonstrated [68] [17, 18, 116]. Besides hypertension, aging, and smoking, there is evidence that all major cardiovascular risk factors (alone or in combination) blunt endothelial function by impairing $\mathrm{NO}$ synthesis or decreasing the bioavailability of the mediator at the vascular level by increasing oxidative stress or reducing the sensitivity of vascular smooth muscle to NO (for review, see [10]).

Therefore, many pharmacological as well as nonpharmacological interventions to decrease oxidative stress have been investigated. Acute administration of antioxidant vitamins (e.g., vitamin $\mathrm{C}$ or $\mathrm{E}$ ) demonstrated amelioration of endothelial dysfunction in different conditions, e.g., in coronary heart disease [54]. However, long-term interventional studies did not show clinical benefits [19, 29]. Recently, other antioxidative compounds such as polyphenols, mainly found in plant-derived nutrition (for example in cocoa in high concentrations), have been shown to improve endothelial function not only by its antioxidative effects but also due to direct induction of NOS $[21,35]$. Many pharmacological interventions have been shown to improve endothelial function due to different mechanisms; however, this would go far beyond the scope of this review [93].

\section{Prostacyclin}

Another important endothelium-derived relaxing factor which is released partly in response to shear stress as well as in response to acetylcholine is $\mathrm{PGI}_{2}[55,69,78,82]$. $\mathrm{PGI}_{2}$ is synthesized by cyclooxygenase (COX) from arachidonic acid [66] and increases cyclic adenosine monophosphate (AMP) in smooth muscle cells as well as in platelets. However, it seems that in contrast to $\mathrm{NO}, \mathrm{PGI}_{2}$ does not contribute to the maintenance of basal vascular tone of large conduit arteries [50]. Also, in the forearm circulation of humans, the response to acetylcholine is unaffected by aspirin suggesting that $\mathrm{PGI}_{2}$ plays a minor role in the control of vascular tone. However, in patients with a decreased NO bioavailability as in atherosclerosis, COX-2-derived prostaglandins can play an important compensatory role $[11,95]$.

Moreover, $\mathrm{PGI}_{2}$ exerts important platelet inhibitory effects. Indeed, $\mathrm{NO}$ and $\mathrm{PGI}_{2}$ synergistically inhibit platelet activity [80]. Interestingly, when endothelial cells are 
stimulated with agonists that increase intracellular calcium, $\mathrm{NO}$ is released continuously [44], whereas $\mathrm{PGI}_{2}$ is released only in a transient manner [65].

In addition, $\mathrm{PGI}_{2}$ facilitates the release of $\mathrm{NO}$ by endothelial cells [86], and conversely, the action of $\mathrm{PGI}_{2}$ in the vascular smooth muscle is potentiated by $\mathrm{NO}$ and NO indirectly prolongs the half-life of cyclic AMP, the second messenger of prostacyclin [27].

\section{Endothelium-derived hyperpolarizing factor(s)}

EDHFs are molecules causing smooth muscle cells to hyperpolarize. Their involvement in the regulation of vascular tone is defined as the response that persists in the presence of combined inhibition of nitric oxide (by L-NMMA) and prostacyclin (by aspirin). They may play an important role as compensatory pathways for endothelium-dependent vasodilatation in the presence of reduced NO availability [101]. In hypertensive patients, for example, vasodilatation due to bradykinin is impaired because of $\mathrm{NO}$ alteration by oxidative stress, but is due to endothelium-dependent hyperpolarization. Thus, vasodilatation is significantly reduced by ouabain, a $\mathrm{Na}(+) \mathrm{K}(+) /$ ATPase inhibitor which blocks hyperpolarization [101]. However, studies examining the relevance of EDHF in humans are rather scarce, mainly due to the fact that commonly used inhibitors of the EDHF pathway are limited by their in vivo toxicity [6].

Studies in the animal have identified several molecules/ mediators that might act as EDHF in different tissues and species [28]. Among them, $\mathrm{K}^{+}$[30], cytochrome $\mathrm{P} 450$ metabolites [14, 57, 103], lipoxygenase products [33], NO itself [7], reactive oxygen species $\left(\mathrm{H}_{2} \mathrm{O}_{2}\right)$ [32], cyclic adenosine monophosphate [79], C-type natriuretic peptide [114], and electrical coupling through myoendothelial gap junctions $[41,42]$. Central to endothelium-dependent hyperpolarization is a potassium-mediated event with a reduction in intracellular $\mathrm{K}^{+}$in vascular smooth muscle which can be triggered by all of above-mentioned mediators [34].

\section{Carbon monoxide}

Carbon monoxide (CO) is generated endogenously partly in the endothelium and may have similar effects as NO including relaxation of vascular smooth muscle cells [113] and antiproliferative actions [49], which are also mediated by an increased production of cGMP. It is, however, less powerful than NO. CO may protect endothelial cells against apoptosis because of its interaction with NF-kappaB [9]. Its role in human disease, however, is not yet clear.

Acknowledgments Our research was supported by the Swiss National Science Foundation (grant no. 3100-068118 and no. 310030118353 to TFL) as well as by the Mercator, the Bonizi-Theler, and the Swiss Heart Foundation.

\section{References}

1. Alp NJ, Channon KM (2004) Regulation of endothelial nitric oxide synthase by tetrahydrobiopterin in vascular disease. Arterioscler Thromb Vasc Biol 24:413-420

2. Anderson EA, Mark AL (1989) Flow-mediated and reflex changes in large peripheral artery tone in humans. Circulation 79:93-100

3. Anderson TJ, Uehata A, Gerhard MD, Meredith IT, Knab S, Delagrage D, Lieberman EH, Ganz P, Creager MA, Yeung AC, Selwyn AP (1995) Close relation of endothelial function in the human coronary and peripheral circulation. J Am Coll Cardiol 26:1235-1241

4. Auch-Schwelk W, Katusic ZS, Vanhoutte PM (1989) Contractions to oxygen-derived free radicals are augmented in aorta of the spontaneously hypertensive rat. Hypertension 13:859-864

5. Barton M, Cosentino F, Brandes RP, Moreau P, Shaw S, Luscher TF (1997) Anatomic heterogeneity of vascular aging: role of nitric oxide and endothelin. Hypertension 30:817-824

6. Bellien J, Thuillez C, Joannides R (2008) Contribution of endothelium-derived hyperpolarizing factors to the regulation of vascular tone in humans. Fundam Clin Pharmacol 22:363-377

7. Bolotina VM, Najibi S, Palacino JJ, Pagano PJ, Cohen RA (1994) Nitric oxide directly activates calcium-dependent potassium channels in vascular smooth muscle. Nature 368:850-853

8. Brevetti G, Silvestro A, Schiano V, Chiariello M (2003) Endothelial dysfunction and cardiovascular risk prediction in peripheral arterial disease: additive value of flow-mediated dilation to ankle-brachial pressure index. Circulation 108:2093-2098

9. Brouard S, Berberat PO, Tobiasch E, Seldon MP, Bach FH, Soares MP (2002) Heme oxygenase-1-derived carbon monoxide requires the activation of transcription factor NF-kappa B to protect endothelial cells from tumor necrosis factor-alphamediated apoptosis. J Biol Chem 277:17950-17961

10. Brunner H, Cockcroft JR, Deanfield J, Donald A, Ferrannini E, Halcox J, Kiowski W, Luscher TF, Mancia G, Natali A, Oliver JJ, Pessina AC, Rizzoni D, Rossi GP, Salvetti A, Spieker LE, Taddei S, Webb DJ (2005) Endothelial function and dysfunction. Part II: association with cardiovascular risk factors and diseases. A statement by the Working Group on Endothelins and Endothelial Factors of the European Society of Hypertension. J Hypertens 23:233-246

11. Bulut D, Liaghat S, Hanefeld C, Koll R, Miebach T, Mugge A (2003) Selective cyclo-oxygenase-2 inhibition with parecoxib acutely impairs endothelium-dependent vasodilatation in patients with essential hypertension. J Hypertens 21:1663-1667

12. Calver A, Collier J, Moncada S, Vallance P (1992) Effect of local intra-arterial NG-monomethyl-L-arginine in patients with hypertension: the nitric oxide dilator mechanism appears abnormal. J Hypertens 10:1025-1031

13. Calver A, Collier J, Vallance P (1992) Inhibition and stimulation of nitric oxide synthesis in the human forearm arterial bed of patients with insulin-dependent diabetes. J Clin Invest 90:25482554

14. Campbell WB, Falck JR (2007) Arachidonic acid metabolites as endothelium-derived hyperpolarizing factors. Hypertension 49:590-596

15. Casino PR, Kilcoyne CM, Quyyumi AA, Hoeg JM, Panza JA (1993) The role of nitric oxide in endothelium-dependent vasodilation of hypercholesterolemic patients. Circulation $88: 2541-2547$

16. Celermajer DS, Sorensen KE, Gooch VM, Spiegelhalter DJ, Miller OI, Sullivan ID, Lloyd JK, Deanfield JE (1992) Noninvasive detection of endothelial dysfunction in children and adults at risk of atherosclerosis. Lancet 340:1111-1115 
17. Celermajer DS, Sorensen KE, Georgakopoulos D, Bull C, Thomas O, Robinson J, Deanfield JE (1993) Cigarette smoking is associated with dose-related and potentially reversible impairment of endothelium-dependent dilation in healthy young adults. Circulation 88:2149-2155

18. Celermajer DS, Adams MR, Clarkson P, Robinson J, McCredie R, Donald A, Deanfield JE (1996) Passive smoking and impaired endothelium-dependent arterial dilatation in healthy young adults. N Engl J Med 334:150-154

19. Cook NR, Albert CM, Gaziano JM, Zaharris E, MacFadyen J, Danielson E, Buring JE, Manson JE (2007) A randomized factorial trial of vitamins $\mathrm{C}$ and $\mathrm{E}$ and beta carotene in the secondary prevention of cardiovascular events in women: results from the Women's Antioxidant Cardiovascular Study. Arch Intern Med 167:1610-1618

20. Corretti MC, Anderson TJ, Benjamin EJ, Celermajer D, Charbonneau F, Creager MA, Deanfield J, Drexler H, GerhardHerman M, Herrington D, Vallance P, Vita J, Vogel R (2002) Guidelines for the ultrasound assessment of endothelialdependent flow-mediated vasodilation of the brachial artery: a report of the International Brachial Artery Reactivity Task Force. J Am Coll Cardiol 39:257-265

21. Corti R, Flammer AJ, Hollenberg NK, Luscher TF (2009) Cocoa and cardiovascular health. Circulation 119:1433-1441

22. Cosentino F, Sill JC, Katusic ZS (1994) Role of superoxide anions in the mediation of endothelium-dependent contractions. Hypertension 23:223-235

23. Cosentino F, Eto M, De Paolis P, van der Loo B, Bachschmid M, Ullrich V, Kouroedov A, Delli Gatti C, Joch H, Volpe M, Luscher TF (2003) High glucose causes upregulation of cyclooxygenase- 2 and alters prostanoid profile in human endothelial cells: role of protein kinase $\mathrm{C}$ and reactive oxygen species. Circulation 107:1017-1023

24. Cosentino F, Hurlimann D, Delli Gatti C, Chenevard R, Blau N, Alp NJ, Channon KM, Eto M, Lerch P, Enseleit F, Ruschitzka F, Volpe M, Luscher TF, Noll G (2008) Chronic treatment with tetrahydrobiopterin reverses endothelial dysfunction and oxidative stress in hypercholesterolaemia. Heart 94:487-492

25. Creager MA, Roddy MA (1994) Effect of captopril and enalapril on endothelial function in hypertensive patients. Hypertension 24:499-505

26. Deanfield J, Donald A, Ferri C, Giannattasio C, Halcox J, Halligan S, Lerman A, Mancia G, Oliver JJ, Pessina AC, Rizzoni D, Rossi GP, Salvetti A, Schiffrin EL, Taddei S, Webb DJ (2005) Endothelial function and dysfunction. Part I: methodological issues for assessment in the different vascular beds: a statement by the Working Group on Endothelin and Endothelial Factors of the European Society of Hypertension. J Hypertens 23:7-17

27. Delpy E, Coste H, Gouville AC (1996) Effects of cyclic GMP elevation on isoprenaline-induced increase in cyclic AMP and relaxation in rat aortic smooth muscle: role of phosphodiesterase 3. Br J Pharmacol 119:471-478

28. Duvall WL (2005) Endothelial dysfunction and antioxidants. Mt Sinai J Med 72:71-80

29. Ebbing M, Bleie O, Ueland PM, Nordrehaug JE, Nilsen DW, Vollset SE, Refsum H, Pedersen EK, Nygard O (2008) Mortality and cardiovascular events in patients treated with homocysteinelowering B vitamins after coronary angiography: a randomized controlled trial. Jama 300:795-804

30. Edwards G, Dora KA, Gardener MJ, Garland CJ, Weston AH (1998) $\mathrm{K}+$ is an endothelium-derived hyperpolarizing factor in rat arteries. Nature 396:269-272

31. Egashira K, Suzuki S, Hirooka Y, Kai H, Sugimachi M, Imaizumi T, Takeshita A (1995) Impaired endotheliumdependent vasodilation of large epicardial and resistance coronary arteries in patients with essential hypertension. Different responses to acetylcholine and substance P. Hypertension 25:201-206

32. Ellis A, Triggle CR (2003) Endothelium-derived reactive oxygen species: their relationship to endothelium-dependent hyperpolarization and vascular tone. Can J Physiol Pharmacol 81:1013-1028

33. Faraci FM, Sobey CG, Chrissobolis S, Lund DD, Heistad DD, Weintraub NL (2001) Arachidonate dilates basilar artery by lipoxygenase-dependent mechanism and activation of $\mathrm{K}(+)$ channels. Am J Physiol Regul Integr Comp Physiol 281:R246-R253

34. Feletou M, Vanhoutte PM (2006) Endothelium-derived hyperpolarizing factor: where are we now? Arterioscler Thromb Vasc Biol 26:1215-1225

35. Flammer AJ, Hermann F, Sudano I, Spieker L, Hermann M, Cooper KA, Serafini M, Luscher TF, Ruschitzka F, Noll G, Corti R (2007) Dark chocolate improves coronary vasomotion and reduces platelet reactivity. Circulation 116:2376-2382

36. Flammer AJ, Sudano I, Hermann F, Gay S, Forster A, Neidhart M, Kunzler P, Enseleit F, Periat D, Hermann M, Nussberger J, Luscher TF, Corti R, Noll G, Ruschitzka F (2008) Angiotensinconverting enzyme inhibition improves vascular function in rheumatoid arthritis. Circulation 117:2262-2269

37. Flammer AJ, Vo NT, Ledergerber B, Hermann F, Gamperli A, Huttner A, Evison J, Baumgartner I, Cavassini M, Hayoz D, Quitzau K, Hersberger M, Sudano I, Ruschitzka F, Luscher TF, Noll G, Weber R (2009) Effect of atazanavir versus other protease inhibitor-containing antiretroviral therapy on endothelial function in HIV-infected persons: randomised controlled trial. Heart 95:385-390

38. Fridovich I, Freeman B (1986) Antioxidant defenses in the lung. Annu Rev Physiol 48:693-702

39. Furchgott RF, Zawadzki JV (1980) The obligatory role of endothelial cells in the relaxation of arterial smooth muscle by acetylcholine. Nature 288:373-376

40. Gokce N, Keaney JF Jr, Hunter LM, Watkins MT, Menzoian JO, Vita JA (2002) Risk stratification for postoperative cardiovascular events via noninvasive assessment of endothelial function: a prospective study. Circulation 105:1567-1572

41. Griffith TM (2004) Endothelium-dependent smooth muscle hyperpolarization: do gap junctions provide a unifying hypothesis? Br J Pharmacol 141:881-903

42. Griffith TM, Chaytor AT, Edwards DH (2004) The obligatory link: role of gap junctional communication in endotheliumdependent smooth muscle hyperpolarization. Pharmacol Res 49:551-564

43. Halcox JP, Schenke WH, Zalos G, Mincemoyer R, Prasad A, Waclawiw MA, Nour KR, Quyyumi AA (2002) Prognostic value of coronary vascular endothelial dysfunction. Circulation 106:653-658

44. Harrington LS, Carrier MJ, Gallagher N, Gilroy D, Garland CJ, Mitchell JA (2007) Elucidation of the temporal relationship between endothelial-derived $\mathrm{NO}$ and EDHF in mesenteric vessels. Am J Physiol Heart Circ Physiol 293:H1682-H1688

45. Heitzer T, Schlinzig T, Krohn K, Meinertz T, Munzel T (2001) Endothelial dysfunction, oxidative stress, and risk of cardiovascular events in patients with coronary artery disease. Circulation 104:2673-2678

46. Hirooka $\mathrm{Y}$, Imaizumi $\mathrm{T}$, Masaki $\mathrm{H}$, Ando S, Harada S, Momohara M, Takeshita A (1992) Captopril improves impaired endothelium-dependent vasodilation in hypertensive patients. Hypertension 20:175-180

47. Hishikawa K, Oemar BS, Yang Z, Luscher TF (1997) Pulsatile stretch stimulates superoxide production and activates nuclear factor-kappa B in human coronary smooth muscle. Circ Res 81:797-803

48. Hurlimann D, Forster A, Noll G, Enseleit F, Chenevard R, Distler O, Bechir M, Spieker LE, Neidhart M, Michel BA, Gay 
RE, Luscher TF, Gay S, Ruschitzka F (2002) Anti-tumor necrosis factor-alpha treatment improves endothelial function in patients with rheumatoid arthritis. Circulation 106:2184-2187

49. Hussain AS, Marks GS, Brien JF, Nakatsu K (1997) The soluble guanylyl cyclase inhibitor $1 \mathrm{H}-[1,2,4]$ oxadiazolo[4, 3-alpha] quinoxalin-1-one (ODQ) inhibits relaxation of rabbit aortic rings induced by carbon monoxide, nitric oxide, and glyceryl trinitrate. Can J Physiol Pharmacol 75:1034-1037

50. Joannides R, Haefeli WE, Linder L, Richard V, Bakkali EH, Thuillez C, Lüscher TF (1995) Nitric oxide is responsible for flow-dependent dilatation of human peripheral conduit arteries in vivo. Circulation 91:1314-1319

51. Joannides R, Richard V, Haefeli WE, Linder L, Lüscher TF, Thuillez C (1995) Role of basal and stimulated release of nitric oxide in the regulation of radial artery caliber in humans. Hypertension 26:327-331

52. Katusic ZS, Vanhoutte PM (1989) Superoxide anion is an endothelium-derived contracting factor. Am J Physiol 257: H33-H37

53. Katusic ZS, Schugel J, Cosentino F, Vanhoutte PM (1993) Endothelium-dependent contractions to oxygen-derived free radicals in the canine basilar artery. Am J Physiol 264:H859H864

54. Kaufmann PA, Gnecchi-Ruscone T, di Terlizzi M, Schafers KP, Luscher TF, Camici PG (2000) Coronary heart disease in smokers: vitamin $\mathrm{C}$ restores coronary microcirculatory function. Circulation 102:1233-1238

55. Koller A, Kaley G (1990) Prostaglandins mediate arteriolar dilation to increased blood flow velocity in skeletal muscle microcirculation. Circ Res 67:529-534

56. Kuvin JT, Patel AR, Sliney KA, Pandian NG, Sheffy J, Schnall RP, Karas RH, Udelson JE (2003) Assessment of peripheral vascular endothelial function with finger arterial pulse wave amplitude. Am Heart J 146:168-174

57. Larsen BT, Gutterman DD, Sato A, Toyama K, Campbell WB, Zeldin DC, Manthati VL, Falck JR, Miura H (2008) Hydrogen peroxide inhibits cytochrome p450 epoxygenases: interaction between two endothelium-derived hyperpolarizing factors. Circ Res 102:59-67

58. Lavie P, Schnall RP, Sheffy J, Shlitner A (2000) Peripheral vasoconstriction during REM sleep detected by a new plethysmographic method. Nat Med 6:606

59. Linder L, Kiowski W, Bühler FR, Lüscher TF (1990) Indirect evidence for release of endothelium-derived relaxing factor in human forearm circulation in vivo. Blunted response in essential hypertension. Circulation 81:1762-1767

60. Ludmer PL, Selwyn AP, Shook TL, Wayne RR, Mudge GH, Alexander RW, Ganz P (1986) Paradoxical vasoconstriction induced by acetylcholine in atherosclerotic coronary arteries. $\mathrm{N}$ Engl J Med 315:1046-1051

61. Maier W, Cosentino F, Lutolf RB, Fleisch M, Seiler C, Hess OM, Meier B, Luscher TF (2000) Tetrahydrobiopterin improves endothelial function in patients with coronary artery disease. J Cardiovasc Pharmacol 35:173-178

62. Makimattila S, Virkamaki A, Groop PH, Cockcroft J, Utriainen T, Fagerudd J, Yki-Jarvinen H (1996) Chronic hyperglycemia impairs endothelial function and insulin sensitivity via different mechanisms in insulin-dependent diabetes mellitus. Circulation 94:1276-1282

63. McAllister AS, Atkinson AB, Johnston GD, Hadden DR, Bell PM, McCance DR (1999) Basal nitric oxide production is impaired in offspring of patients with essential hypertension. Clin Sci (Colch) 97:141-147

64. Millgard J, Lind L (1998) Acute hypertension impairs endothelium-dependent vasodilation. Clin Sci (Colch) 94:601607
65. Mitchell JA, de Nucci G, Warner TD, Vane JR (1992) Different patterns of release of endothelium-derived relaxing factor and prostacyclin. Br J Pharmacol 105:485-489

66. Moncada S, Gryglewski R, Bunting S, Vane JR (1976) An enzyme isolated from arteries transforms prostaglandin endoperoxides to an unstable substance that inhibits platelet aggregation. Nature 263:663-665

67. Neunteufl T, Heher S, Katzenschlager R, Wolfl G, Kostner K, Maurer G, Weidinger F (2000) Late prognostic value of flowmediated dilation in the brachial artery of patients with chest pain. Am J Cardiol 86:207-210

68. Newby DE, Wright RA, Labinjoh C, Ludlam CA, Fox KA, Boon NA, Webb DJ (1999) Endothelial dysfunction, impaired endogenous fibrinolysis, and cigarette smoking: a mechanism for arterial thrombosis and myocardial infarction. Circulation 99:1411-1415

69. Okahara K, Sun B, Kambayashi J (1998) Upregulation of prostacyclin synthesis-related gene expression by shear stress in vascular endothelial cells. Arterioscler Thromb Vasc Biol 18:1922-1926

70. Palmer RM, Ferrige AG, Moncada S (1987) Nitric oxide release accounts for the biological activity of endothelium-derived relaxing factor. Nature 327:524-526

71. Palmer RM, Ashton DS, Moncada S (1988) Vascular endothelial cells synthesize nitric oxide from L-arginine. Nature 333:664-666

72. Palmer RMJ, Rees DD, Ashton DS, Moncada S (1988) LArginine is the physiological precursor for the formation of nitric oxide in endothelium-dependent relaxation. Biochem Biophys Res Commun 153:1251-1256

73. Panza JA, Quyyumi AA, Brush JJ, Epstein SE (1990) Abnormal endothelium-dependent vascular relaxation in patients with essential hypertension. N Engl J Med 323:22-27

74. Panza JA, Casino PR, Badar DM, Quyyumi AA (1993) Effect of increased availability of endothelium-derived nitric oxide precursor on endothelium-dependent vascular relaxation in normal subjects and in patients with essential hypertension. Circulation 87:1475-1481

75. Panza JA, Casino PR, Kilcoyne CM, Quyyumi AA (1993) Role of endothelium-derived nitric oxide in the abnormal endothelium-dependent vascular relaxation of patients with essential hypertension. Circulation 87:1468-1474

76. Panza JA, Quyyumi AA, Callahan TS, Epstein SE (1993) Effect of antihypertensive treatment on endothelium-dependent vascular relaxation in patients with essential hypertension. J Am Coll Cardiol 21:1145-1151

77. Panza JA, Casino PR, Kilcoyne CM, Quyyumi AA (1994) Impaired endothelium-dependent vasodilation in patients with essential hypertension: evidence that the abnormality is not at the muscarinic receptor level. J Am Coll Cardiol 23:1610-1616

78. Pohl U, Holtz J, Busse R, Bassenge E (1986) Crucial role of endothelium in the vasodilator response to increased flow in vivo. Hypertension 8:37-44

79. Popp R, Brandes RP, Ott G, Busse R, Fleming I (2002) Dynamic modulation of interendothelial gap junctional communication by 11, 12-epoxyeicosatrienoic acid. Circ Res 90:800-806

80. Radomski MW, Palmer RM, Moncada S (1987) Comparative pharmacology of endothelium-derived relaxing factor, nitric oxide and prostacyclin in platelets. Br J Pharmacol 92:181-187

81. Rossi GP, Taddei S, Virdis A, Cavallin M, Ghiadoni L, Favilla S, Versari D, Sudano I, Pessina AC, Salvetti A (2003) The T-786C and Glu298Asp polymorphisms of the endothelial nitric oxide gene affect the forearm blood flow responses of Caucasian hypertensive patients. J Am Coll Cardiol 41:938-945

82. Rubanyi GM, Romero JC, Vanhoutte PM (1986) Flow-induced release of endothelium-derived relaxing factor. Am J Physiol 250:H1145-H1149 
83. Rubanyi GM, Vanhoutte PM (1986) Superoxide anions and hyperoxia inactivate endothelium-derived relaxing factor. Am J Physiol 250:H822-H827

84. Schachinger V, Britten MB, Zeiher AM (2000) Prognostic impact of coronary vasodilator dysfunction on adverse long-term outcome of coronary heart disease. Circulation 101:1899-1906

85. Schindler TH, Hornig B, Buser PT, Olschewski M, Magosaki N, Pfisterer M, Nitzsche EU, Solzbach U, Just H (2003) Prognostic value of abnormal vasoreactivity of epicardial coronary arteries to sympathetic stimulation in patients with normal coronary angiograms. Arterioscler Thromb Vasc Biol 23:495-501

86. Shimokawa H, Flavahan NA, Lorenz RR, Vanhoutte PM (1988) Prostacyclin releases endothelium-derived relaxing factor and potentiates its action in coronary arteries of the pig. Br J Pharmacol 95:1197-1203

87. Shimokawa H, Yasutake H, Fujii K, Owada MK, Nakaike R, Fukumoto Y, Takayanagi T, Nagao T, Egashira K, Fujishima M, Takeshita A (1996) The importance of the hyperpolarizing mechanism increases as the vessel size decreases in endothelium-dependent relaxations in rat mesenteric circulation. J Cardiovasc Pharmacol 28:703-711

88. Smits P, Kapma JA, Jacobs MC, Lutterman J, Thien T (1993) Endothelium-dependent vascular relaxation in patients with type I diabetes. Diabetes 42:148-153

89. Spieker LE, Sudano I, Hurlimann D, Lerch PG, Lang MG, Binggeli C, Corti R, Ruschitzka F, Luscher TF, Noll G (2002) High-density lipoprotein restores endothelial function in hypercholesterolemic men. Circulation 105:1399-1402

90. Stamler JS, Singel DJ, Loscalzo J (1992) Biochemistry of nitric oxide and its redox-activated forms. Science 258:1898-1902

91. Steinberg HO, Chaker H, Leaming R, Johnson A, Brechtel G, Baron AD (1996) Obesity/insulin resistance is associated with endothelial dysfunction. Implications for the syndrome of insulin resistance. J Clin Invest 97:2601-2610

92. Stroes E, Kastelein J, Cosentino F, Erkelens W, Wever R, Koomans H, Luscher T, Rabelink T (1997) Tetrahydrobiopterin restores endothelial function in hypercholesterolemia. J Clin Invest 99:41-46

93. Sudano I, Spieker LE, Hermann F, Flammer A, Corti R, Noll G, Luscher TF (2006) Protection of endothelial function: targets for nutritional and pharmacological interventions. J Cardiovasc Pharmacol 47(Suppl 2):S136-S150, discussion S172-6

94. Suwaidi JA, Hamasaki S, Higano ST, Nishimura RA, Holmes DR Jr, Lerman A (2000) Long-term follow-up of patients with mild coronary artery disease and endothelial dysfunction. Circulation 101:948-954

95. Szerafin T, Erdei N, Fulop T, Pasztor ET, Edes I, Koller A, Bagi Z (2006) Increased cyclooxygenase-2 expression and prostaglandin-mediated dilation in coronary arterioles of patients with diabetes mellitus. Circ Res 99:e12-e17

96. Taddei S, Virdis A, Mattei P, Arzilli F, Salvetti A (1992) Endothelium-dependent forearm vasodilation is reduced in normotensive subjects with familial history of hypertension. J Cardiovasc Pharmacol 20:S193-S195

97. Taddei S, Mattei P, Virdis A, Sudano I, Ghiadoni L, Salvetti A (1994) Effect of potassium on vasodilation to acetylcholine in essential hypertension. Hypertension 23:485-490

98. Taddei S, Virdis A, Mattei P, Ghiadoni L, Gennari A, Fasolo CB, Sudano I, Salvetti A (1995) Aging and endothelial function in normotensive subjects and patients with essential hypertension. Circulation 91:1981-1987

99. Taddei S, Virdis A, Mattei P, Ghiadoni L, Fasolo CB, Sudano I, Salvetti A (1997) Hypertension causes premature aging of endothelial function in humans. Hypertension 29:736-743

100. Taddei S, Virdis A, Ghiadoni L, Magagna A, Salvetti A (1998) Vitamin $\mathrm{C}$ improves endothelium-dependent vasodilation by restoring nitric oxide activity in essential hypertension. Circulation 97:2222-2229

101. Taddei S, Ghiadoni L, Virdis A, Buralli S, Salvetti A (1999) Vasodilation to bradykinin is mediated by an ouabain-sensitive pathway as a compensatory mechanism for impaired nitric oxide availability in essential hypertensive patients. Circulation 100:1400-1405

102. Taddei S, Galetta F, Virdis A, Ghiadoni L, Salvetti G, Franzoni F, Giusti C, Salvetti A (2000) Physical activity prevents agerelated impairment in nitric oxide availability in elderly athletes. Circulation 101:2896-2901

103. Taddei S, Versari D, Cipriano A, Ghiadoni L, Galetta F, Franzoni F, Magagna A, Virdis A, Salvetti A (2006) Identification of a cytochrome P450 2C9-derived endothelium-derived hyperpolarizing factor in essential hypertensive patients. J Am Coll Cardiol 48:508-515

104. Targonski PV, Bonetti PO, Pumper GM, Higano ST, Holmes DR Jr, Lerman A (2003) Coronary endothelial dysfunction is associated with an increased risk of cerebrovascular events. Circulation 107:2805-2809

105. Tawakol A, Forgione MA, Stuehlinger M, Alpert NM, Cooke JP, Loscalzo J, Fischman AJ, Creager MA, Gewirtz H (2002) Homocysteine impairs coronary microvascular dilator function in humans. J Am Coll Cardiol 40:1051-1058

106. Thomson L, Trujillo M, Telleri R, Radi R (1995) Kinetics of cytochrome $\mathrm{c} 2+$ oxidation by peroxynitrite: implications for superoxide measurements in nitric oxide-producing biological systems. Arch Biochem Biophys 319:491-497

107. Treasure CB, Klein JL, Vita JA, Manoukian SV, Renwick GH, Selwyn AP, Ganz P, Alexander RW (1993) Hypertension and left ventricular hypertrophy are associated with impaired endotheliummediated relaxation in human coronary resistance vessels. Circulation 87:86-93

108. Tschudi MR, Barton M, Bersinger NA, Moreau P, Cosentino F, Noll G, Malinski T, Luscher TF (1996) Effect of age on kinetics of nitric oxide release in rat aorta and pulmonary artery. J Clin Invest 98:899-905

109. Tschudi MR, Mesaros S, Luscher TF, Malinski T (1996) Direct in situ measurement of nitric oxide in mesenteric resistance arteries. Increased decomposition by superoxide in hypertension. Hypertension 27:32-35

110. Turrens JF, Boveris A (1980) Generation of superoxide anion by the NADH dehydrogenase of bovine heart mitochondria. Biochem J 191:421-427

111. Vallance P, Collier J, Moncada S (1989) Effects of endotheliumderived nitric oxide on peripheral arteriolar tone in man. Lancet 2:997-1000

112. van der Loo B, Labugger R, Skepper JN, Bachschmid M, Kilo J, Powell JM, Palacios-Callender M, Erusalimsky JD, Quaschning T, Malinski T, Gygi D, Ullrich V, Luscher TF (2000) Enhanced peroxynitrite formation is associated with vascular aging. J Exp Med 192:1731-1744

113. Wang R, Wang Z, Wu L (1997) Carbon monoxide-induced vasorelaxation and the underlying mechanisms. Br J Pharmacol 121:927-934

114. Wei CM, Hu S, Miller VM, Burnett JC Jr (1994) Vascular actions of $\mathrm{C}$-type natriuretic peptide in isolated porcine coronary arteries and coronary vascular smooth muscle cells. Biochem Biophys Res Commun 205:765-771

115. Wilkinson IB, Fuchs SA, Jansen IM, Spratt JC, Murray GD, Cockcroft JR, Webb DJ (1998) Reproducibility of pulse wave velocity and augmentation index measured by pulse wave analysis. J Hypertens 16:2079-2084

116. Zeiher AM, Schachinger V, Minners J (1995) Long-term cigarette smoking impairs endothelium-dependent coronary arterial vasodilator function. Circulation 92:1094-1100 